Acta vet. scand. $1984,25,385-402$.

From the Department of Physiology, Karolinska Institutet, Stockholm, Sweden.

\title{
NEUROGENIC AND MYOGENIC RESPONSES IN ISOLATED SMOOTH MUSCLE OF THE BOVINE TEAT
}

\author{
By \\ Axel Isaksson and Nils O. Sjöstrand
}

\begin{abstract}
ISAKSSON, A. and N. O. SJÖSTRAND: Neurogenic and myogenic responses in isolated smooth muscle of the bovine teat. Acta vet. scand. 1984, 25, 385 - 402. — Strips of bovine teat smooth muscle were studied. Their innervation was investigated with analytical pharmacology on field stimulated preparations. The content of noradrenaline in the teat wall and the sphincter region was determined. The main results were: teat smooth muscle has properties of single unit smooth muscle i.e. automaticity and active response to stretch. Especially the sphincter region is inclined to rapid phasic rhythmicity. The teat smooth muscle receives excitatory adrenergic innervation. The noradrenaline released from the nerves preferentially activates $\alpha$-adrenoceptors, while $\beta$-adrenoceptors essentially are noninnervated and humoral. The sphincter region has a higher concentration of noradrenaline and a more intimate neuro-effector arrangement. This is probably of functional significance. Moderate chilling increases the response to adrenergic nerve stimulation while it is decreased at higher temperatures. This has most likely physiological importance. The results are discussed with respect to in vivo findings and it is concluded that the bovine teat smooth muscle with its excitatory adrenergic nerves forms a normally very efficient neuro-effector system with a particular strength in the sphincter around the streak canal.
\end{abstract}

mammary gland; cow; autonomic innervation; a drenergic neurotransmission.

The bovine udder is composed of 4 glands (quarters), each of which furnished with a teat. The teat consists of a more or less cylindrical tube with a teat cistern, or sinus, and a teat tip with the streak canal. Proximally the teat cistern communicates with a gland (quarter) cistern, or sinus, which is a receptaculum for the milk produced between milkings by the approximately 10 lobes constituting each gland. Between skin and cisternal membrane, the teat wall is amply supplied with smooth muscle bund- 
les, principally running a longitudinal or a circular course. In the teat tip, circular bundles are condensed to a sphincter around the streak canal. When the canal lumen is empty it is star-shaped. The corresponding ridges of the canal contain longitudinal smooth muscle bundles. Scattered muscle bundles, some of them of considerable thickness, are present in the outer lower quarter cisternal wall.

Sensory and myomotor but no secretomotor innervation of the udder has been reported, the myomotor fibres following the external spermatic (inguinal) and perineal nerves. It is generally considered that these fibres emanate from the sympathetic trunks. Peeters (1978) in summarizing research done by him and his group since 1948, states that teat contraction and vasoconstriction follow stimulation of the nerves of the isolated bovine udder. Experiments with sympathomimetics have demonstrated the presence of both $\alpha$ - and $\beta$-adrenoceptors in teat smooth muscle. $\alpha$-adrenoceptor agonists produce contraction while $\beta$ adrenoceptor agonists produce relaxation. Noradrenaline seems to act preferentially on the $\alpha$-adrenoceptors, while the effect of adrenaline varies. Peeters proposes that the rhythmical teat contractions often seen in the living cow before milking are reactions to stretch of the teat muscle by milk accumulating under pressure in the teat cistern. Rhythmical teat contractions are also seen in teats of isolated udders and hence presumably myogenic in origin. Peeters has also suggested that the motility of teat smooth muscle could be influenced also by endogenous catecholamines acting on $\alpha$ - and/or $\beta$-adrenoceptors. Linzell (1974) reviews pertinent reports published by him and his associates and by others on the in vivo reactions of the mammary glands in various species, including the cow, when sympathomimetics are injected intravenously or when the nerves to the udder are stimulated. He concludes that the result is vasoconstriction and teat contraction.

The aim of this study was to further analyze the basal properties of teat smooth muscle. We have investigated isolated strips taken from the teat wall, the sphincter and the ridges of the streak canal. The nature of the motor innervation and the response to nerve and direct muscle stimulation has been scrutinized by analytical pharmacology on field stimulated muscle. During in vivo conditions there will be great differences in the degree of stretch of the muscle due to, e.g., changes in cisternal 
pressure combined with external forces produced by milking or sucking. Therefore we have studied the effect of stretch on the muscle. Furthermore, during in vivo conditions the teat will be subjected to great temperature variation. A chilled teat may be rapidly warmed by the milk flow, the increased vascular perfusion and the mouth of the suckling. Teat temperature may also be influenced, in either direction, by the temperature of the cleaning water and the teatcup. Therefore we have investigated the effect of temperature changes with special reference to the response to nerve stimulation. In the discussion some extrapolations to in vivo conditions will be suggested.

\section{MATERIAL AND METHODS}

\section{Specimens}

Smooth muscle preparations from teat obtained from 28 cows of different age, breed and yield were studied. The teats and corresponding quarters were macroscopically normal. Teat specimens were excised immediately after slaughter and transported to the laboratory in $4{ }^{\circ} \mathrm{C}$ Ringer solution. Longitudinal and transversal strips were prepared from the muscle layer. In the figures the strips will be referred to as wall longitudinal and wall circular, respectively. Transversal strips were also prepared from the teat canal sphincter and longitudinal strips were excised from the teat canal ridges. In the text and figures these strips will be referred to as sphincter and ridge, respectively. The smooth muscle strips measured $1-3 \mathrm{~mm}$ in thickness, $2-4 \mathrm{~mm}$ in breadth and $5-25 \mathrm{~mm}$ in length. All strips were mounted in Tyrode solution aerated with $6.5 \% \mathrm{CO}_{2}$ in $\mathrm{O}_{2}$ and stretched lightly to moderately $(5-20 \mathrm{mN})$. Organ baths of $20 \mathrm{ml}$ were used in field stimulation experiments and in experiments where the preparations were subjected to stretch or changes in temperature. In some experiments when only the effect of certain drugs was investigated the bath volume was $5 \mathrm{ml}$.

\section{Field stimulation}

The strips were mounted between two parallel platinum electrodes (10 $\mathrm{mm}$ long and $5 \mathrm{~mm}$ apart). Transmural stimulation of nerves was performed with square wave pulses of $0.05-0.5 \mathrm{~ms}$. Usually the pulse width was $0.2 \mathrm{~ms}$ and voltage was just beneath 
supramaximal strength. Supramaximal voltage was defined according to Klinge \& Sjöstrand (1977), i.e. tetrodotoxin (TTX, $3 \mu \mathrm{mol} / \mathrm{l}$ ) was used as a neuron blocker in order to test the neurogenic origin of the studied response. In most experiments the voltage was $10-15 \mathrm{~V}$. It was easy to obtain TTX resistant responses particularly when stimulation frequency was high. Therefore proper frequency response analyses could not be performed and in most experiments the frequency was purposally kept at the lowest possible rate giving steady responses. In most experiments $10 \mathrm{~Hz}$ was the used frequency. The preparations were stimulated for $5-20 \mathrm{~s}$ at $3-5 \mathrm{~min}$ intervals. In some experiments direct smooth muscle stimulation was performed with pulses of 5-10 ms duration and TTX present in the bath (cf. Sjöstrand \& Swedin 1976). Shocks were delivered by a Grass S-44 stimulator with an extra power supply made in the laboratory. Stimulations were monitored by timers made in the laboratory.

Mechanical responses were recorded isometrically with a Grass force displacement transducer (FT 03B) coupled to a Grass polygraph (7).

Usually the bath temperature was $34-35^{\circ} \mathrm{C}$. Changes in temperature were effected either by a rapid and abrupt change of the water surrounding the bath or by resetting the thermostat tempering the water. In the latter case the change in temperature was gradual and rather slow. In the figures the direction of temperature changes is indicated. Triangles indicate abrupt changes in temperature.

\section{Determination of noradrenaline}

The right hind teat of 5 heifers was transported to the laboratory chilled by ice. About $2 \mathrm{~g}$ of tissue was taken from the teat wall. Each sample comprised material from 4 different sites of the wall. The sphincter of the teat was also dissected free $(0.2-$ $0.3 \mathrm{~g})$. The ice-cold tissue specimens were cut into small pieces, weighed and homogenized in $15 \mathrm{ml}$ of ice-cold $0.4 \mathrm{~mol} / \mathrm{l}$ perchloric acid with an Ultra Thurrax apparatus. Extraction, absorption and elution of the noradrenaline were performed as described by Sjöstrand \& Swedin (1976). The noradrenaline was determined with the trihydroxyindole method according to Chang (1964). 
Composition of the Tyrode solution

$\mathrm{NaCl} 136.7 \mathrm{mmol} / \mathrm{l}, \mathrm{KCl} 2.7 \mathrm{mmol} / \mathrm{l}, \mathrm{NaHCO}_{3} 11.9 \mathrm{mmol} / \mathrm{l}$, $\mathrm{CaCl}_{2} 1.8 \mathrm{mmol} / \mathrm{l}, \mathrm{MgCl}_{2} 0.5 \mathrm{mmol} / \mathrm{l}, \mathrm{NaHPO}_{4} 0.3 \mathrm{mmol} / \mathrm{l}$ and glucose $5.6 \mathrm{mmol} / \mathrm{l}$.

\section{Drugs}

Tetrodotoxin (Sigma), l-noradrenaline-d-bitartrate (Sigma), 1-adrenaline-d-bitartrate (Sigma), isoprenaline sulphate (Abbot), terbutaline sulphate (Draco), phentolamine hydrochloride (Ciba), phenoxybenzamine hydrochloride (Smith Cline \& French), sotalol hydrochloride (Regis), guanethidine sulphate (Ciba), bretyllium tosylate (Burroughs Wellcome), acetylcholine chloride (Roche), atropine sulphate (ACO), scopolamine bromide (Sigma), oxytocin (Ferring), arginine-vasopressin (Ferring) and barium chloride (Sigma).

\section{RESULTS}

Automaticity, development of tone and response to stretch

Unstimulated preparations of all types often showed spontaneous activity. The activity was either a slow development of tone or rhythmic phasic contractions. In some preparations tonic waves with 5-10 min intervals were seen. In the sphincter preparations phasic automaticity dominated, while wall preparations usually displayed activity of slow tonic type. No clear-cut difference was noted between longitudinal and transversal strips from the wall.

To rapid stretch (Fig. 1) teat smooth muscle responded with active contraction. In sphincter muscle an increase in frequency of phasic contractions was the dominant response. The increase in frequency was to a certain extent depending on the degree of the stretch as seen in Fig $1 \mathrm{~B}$ and $\mathrm{C}$. In wall strips a more prolonged tonic contraction was the typical response to stretch (Fig. 1A). The response to stretch often persisted for several minutes after unloading.

Effects of neurotransmitters, posterior pituitary hormones and other drugs

Acetylcholine up to $15 \mu \mathrm{mol} / \mathrm{l}$ had no or a weak contractile effect. Noradrenaline and adrenaline $0.3-30 \mu \mathrm{mol} / \mathrm{l}$ contracted teat smooth muscle and increased the frequency of 
A WALL LONGITUDINAL

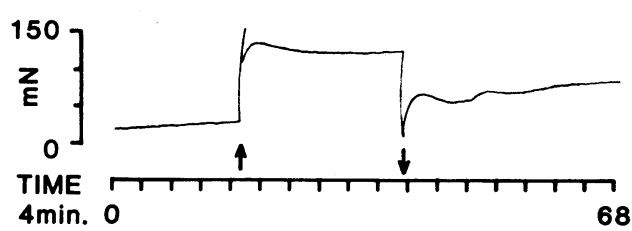

C "SPHINCTER"
B "SPHINCTER"

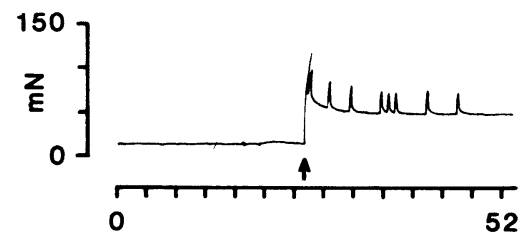

D

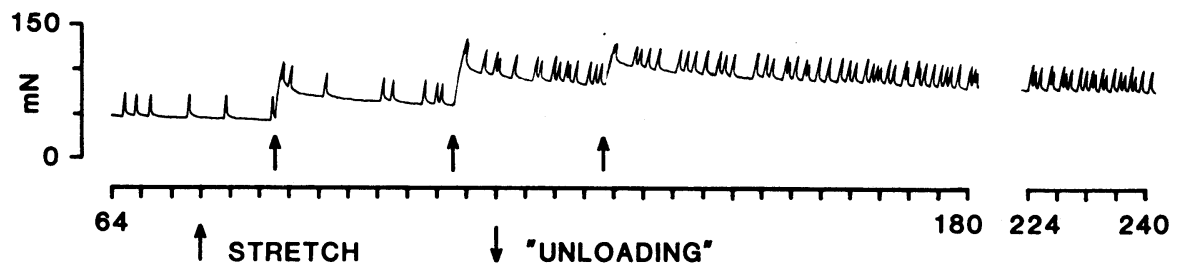

F i g u r e 1. Active response to stretch of bovine teat smooth muscle. $A$. A longitudinal strip from the muscle wall of the teat cistern is slowly developing tone. Sudden stretch induces a contraction of considerable duration. Active response proceeds after unloading. $B$ and $C$. Sudden stretch of a teat tip sphincter strip induces phasic contractions. As seen in $C$ which is a continuous record from $B$ the frequency of rhythmic contractions increases when the strip is further stretched. As seen in $D$ the pattern with fast high frequency contractions persists for a long time when the preparation is stretched.

rhythmic contractions if present. In silent preparations rhythmicity could be provoked by these cathecolamines. In untreated preparations adrenaline and noradrenaline sometimes produced relaxation (cf. Fig. 3) but in most preparations the predominant effect was contraction. The contractile effect of adrenaline and noradrenaline was abolished by the $\alpha$-adrenoceptor blockers phentolamine $(0.016-1.6 \mu \mathrm{mol} / \mathrm{l})$ and phenoxybenzamine $(0.015$ $-1.5 \mu \mathrm{mol} / \mathrm{l})$. Relaxation of the strips and suppression of their automaticity if present was produced by the $\beta$-adrenoceptor stimulants isoprenaline $(0.03-3 \mu \mathrm{mol} / \mathrm{l})$ and terbutaline $0.01-1$ $\mu \mathrm{mol} / \mathrm{l})$. These effects were counteracted by sotalol (3.7-37 $\mu \mathrm{mol} / \mathrm{l})$. Accordingly the presence of both $\alpha$ - and $\beta$-adrenoceptors in bovine teat smooth muscle was confirmed (cf. Peeters $1978)$. No overt effect was seen after oxytocin $(0.01-0.2 \mathrm{IU} / \mathrm{ml})$ or vasopressin $(0.01-0.1 \mathrm{IU} / \mathrm{ml}) . \mathrm{Ba}^{2+}(48-144 \mu \mathrm{mol} / \mathrm{l})$ increased the tone of the smooth muscle strips and provoked rhythmic contractions of them. The contractile effect of $\mathrm{Ba}^{2+}$ was used in the investigation of inhibitory responses to nerve stimulation (see below). 
Response to field stimulation of intramural nerves (Fig. 2)

All preparations responded to field stimulation of the intramural nerves with contraction. The contraction was abolished by the adrenergic neuron blocking agents guanethidine ( $3-30$ !mol/l) and bretyllium $(25-100 \mu \mathrm{mol} / \mathrm{l})$. The response to nerve stimulation was also blocked by the $\alpha$-adrenoceptor blocker phentolamine $(0.3-15 \mu \mathrm{mol} / \mathrm{l})$. There was, however, a certain dif-

\section{"SPHINCTER"}
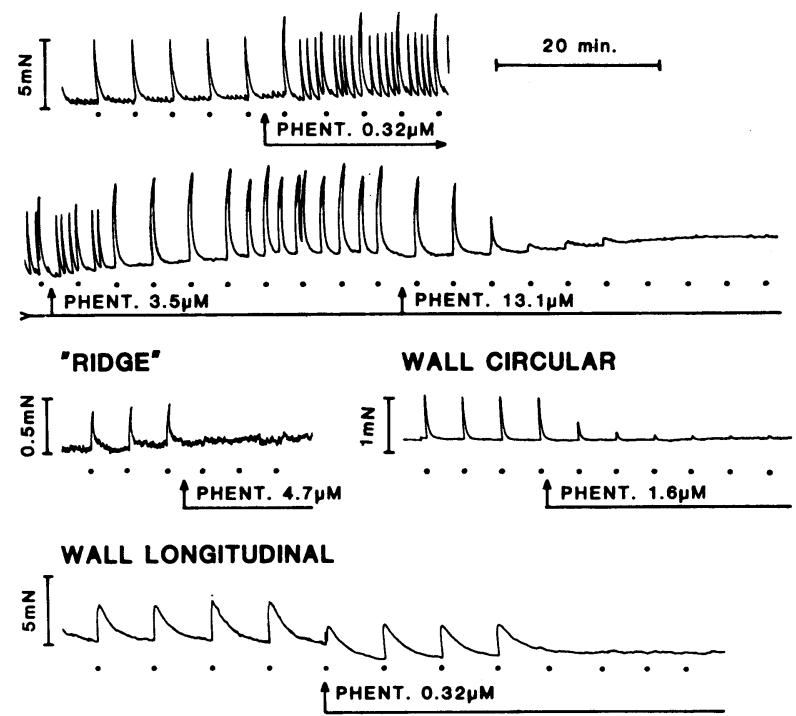

WALL CIRCULAR

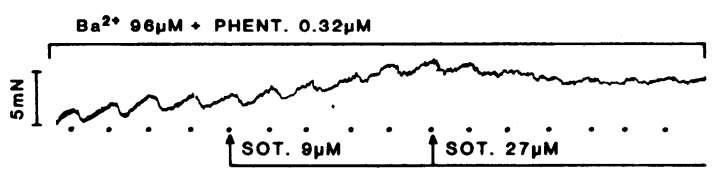

Figure 2. Effect of adrenoceptor blocking agents on the response to field stimulation of intramural nerves in bovine teat smooth muscle. Upper curves, a low dose of phentolamine enhances the response of the sphincter to field stimulation $(0.1 \mathrm{~ms}, 10 \mathrm{~Hz}$ for $15 \mathrm{~s}$ at $5 \mathrm{~min}$ intervals). It also increases the spontaneous activity. When the dose of phentolamine is gradually increased potentiation swifts to complete inhibition. Middle tracings in strips from the teat canal ridge and cisternal wall, phentolamine blocks the response promptly (stimulation patterns the same as above). Lowest tracing, in a preparation kept in tone by barium and subjected to $\alpha$-adrenergic blockade by phentolamine, field stimulation produces a slowly developing relaxation. The relaxation is blocked by sotalol. (Stimulation parameters $0.1 \mathrm{~ms}, 15 \mathrm{~Hz}$, for $20 \mathrm{~s}$ every $5 \mathrm{~min}$ ). 
ference in sensitivity to $\alpha$-adrenoceptor blockade among the different preparations. Thus, the sphincter was less sensitive than strips from the wall. In sphincter strips low doses of phentolamine often produced enhancement of the response to nerve stimulation while it was blocked by higher concentrations. Fig. 2 shows representative experiments. In the sphincter there is conspicuous enhancement of the response by a low dose of phentolamine and also increased spontaneous activity while a higher dose leads to a complete extinction of the response. The responses of ridge and wall preparations are, however, blocked by low or moderate concentrations of the $\alpha$-blocker. Phenoxybenzamine $(0.15-1.5 \mu \mathrm{mol} / \mathrm{l})$ had similar effects as phentolamine.

We never observed any effect other than contraction in untreated field stimulated preparations. However, if the tone was raised by barium and phentolamine was present in the bath a relaxant effect could be seen on high frequency stimulation provided the pulse train had a long duration (Fig. 2). These relaxations developed maximum depth long after interruption of the train. The relaxations were counteracted by sotalol $(9-30 \mu \mathrm{mol} / \mathrm{l})$ and guanethidine. The responses to field stimulation of nerves was not overtly affected by scopolamine $(0.26-2.6 \mu \mathrm{mol} / \mathrm{l})$ or atropine $(0.29-2.9 \mu \mathrm{mol} / \mathrm{l})$.

\section{Content of noradrenaline}

The content of the adrenergic neurotransmitter was moderate in the teat wall, i.e. $73 \pm 19 \mathrm{ng} / \mathrm{g}$. However, the sphincter contained rather large amounts of noradrenaline, i.e. $221 \pm 27 \mathrm{ng} / \mathrm{g}$ (mean $\pm s, n=5$, noradrenaline expressed as base/wet weight).

\section{Effect of direct electrical stimulation of the smooth muscle}

Stimulation of TTX paralyzed muscle with 5-10 ms pulses at $10 \mathrm{~Hz}$ for $10-20 \mathrm{~s}$ produced strong contraction which often lasted for some minutes. Guanethidine and phentolamine enhanced these contractions while sotalol had no overt effect. Noradrenaline and acrenaline usually increased the contractions elicited by direct smooth muscle stimulation. However, in some experiments inhibition could be recorded (Fig. 3). As seen in the figure the suppressive action of noradrenaline could be mimicked 
WALL LONGITUDINAL

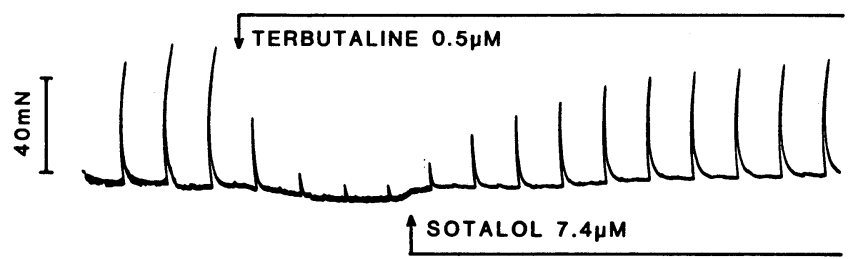

WALL LONGITUDINAL

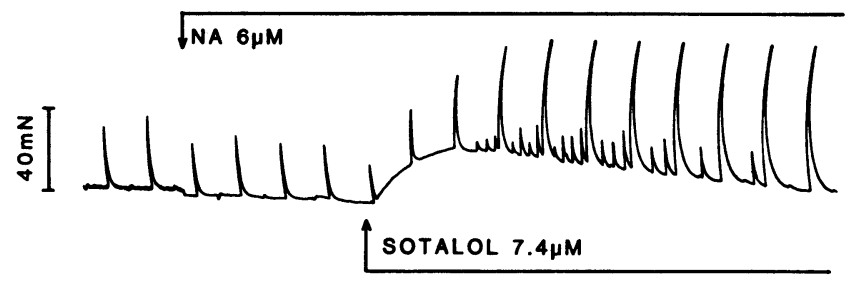

Figure 3. $\beta$-adrenergic effects in teat smooth muscle subjected to direct muscle stimulation $(5 \mathrm{~ms}, 10 \mathrm{~Hz}$ for $10 \mathrm{~s}$ at 5 min intervals). Upper tracing, terbutaline suppresses the response and relaxes the preparation. Sotalol counteracts the effect of terbutaline. Lower tracing, noradrenaline produces certain relaxation. When sotalol is introduced the effect of noradrenaline changes to pure stimulation.

by terbutaline and counteracted by sotalol. After sotalol noradrenaline produced strong and clear-cut enhancement of the response to direct electrical stimulation of the smooth muscle.

Effect of changes in temperature (Figs. 4, 5, 6 and 7)

E f f e c t of chilling. Abrupt chilling of the preparations (from $34-35^{\circ} \mathrm{C}$ to $25-10^{\circ} \mathrm{C}$ ) always contracted the strips. The contraction developed maximum within 5-15 min whereafter it declined despite continuous chilling (Figs. 4 and 5). The response to field stimulation of nerves increased in size and became prolonged if the temperature was lowered to $20-25^{\circ} \mathrm{C}$ (Figs. 4A and 5C). Further chilling of the preparation, i.e. to $10-15^{\circ} \mathrm{C}$ blocked the neurogenic contractile response to field stimulation (Fig. 5A) although stimulation with 5-10 ms pulses still could elicit contractions. The neurogenic contractile response reappeared after warming (Fig. 5B). Gradual decreases in temperature produced by resetting of the thermostat had usually very slight effects on the tone of the preparations. The effect on the 
WALL LONGITUDINAL
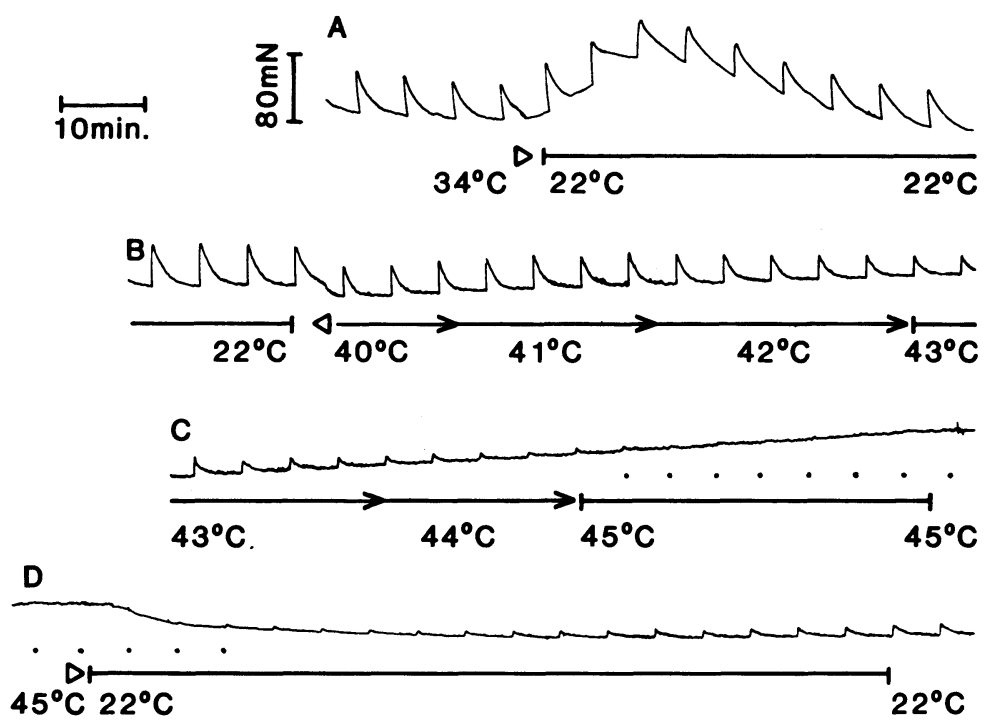

$\mathrm{Figure} 4$. Effect of changes in temperature on tone and contractile response to field stimulation of intramural nerves $(0.1 \mathrm{~ms}, 10 \mathrm{~Hz}$ for $10 \mathrm{~s}$ at $5 \mathrm{~min}$ intervals) in a longitudinal strip from the wall of the teat cistern. A. Rapid cooling of the preparation induces contraction and prolongs the contractile response to nerve stimulation. $B$. Sudden heating of the preparation produces relaxation and decrease in size of the response to nerve stimulation. When the preparation is gradually heated from $40^{\circ} \mathrm{C}$ to $45^{\circ} \mathrm{C}$ there is continuous decrease in size of the response to nerve stimulation, which as seen in $C$ is eliminated at the highest temperature. Concomitantly the tone of the preparation increases. $D$. Following cooling the preparation relaxes and the response to nerve stimulation gradually reappears.

neurogenic contractile response to field stimulation was, however, similar to that of rapid chilling.

E f f e c $t$ of $w$ a $\mathbf{m}$ i n g. Rapid heating of the preparations to $39-45^{\circ} \mathrm{C}$ had diverse effects on them. Some muscles responded with prompt relaxation (Fig. 6B), others with immediate contraction (Figs. 6A, B). As exemplified in Fig. 6B similar strips from the same udder could behave differently. However, during prolonged exposure to warmth most preparations developed an increase in tone. If the temperature was elevated gradually the increase in basal tone of the strips was clear (Figs. 4B, C, 7B). 


\section{WALL LONGITUDINAL}
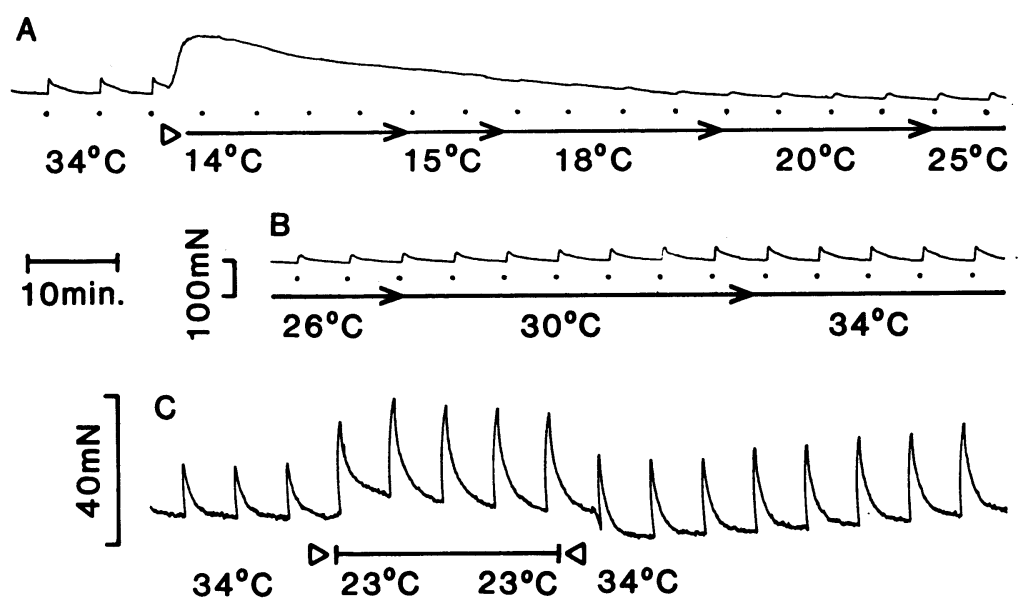

F ig u r e 5. Effect of changes in temperature on strips from the teat wall. $A$. When the preparation is rapidly cooled to $14^{\circ} \mathrm{C}$ there is prompt contraction and abolition of the response to nerve stimulation $(0.1 \mathrm{~ms}, 8 \mathrm{~Hz}$ for $15 \mathrm{~s}$ at $5 \mathrm{~min}$ intervals $)$. When the preparation is gradually warmed the contractile response to nerve stimulation gradually reappears $(A$ and $B)$. $C$. In another preparation stimulated with the same parameters as $A$ and $B$ cooling to $23^{\circ} \mathrm{C}$ increases size and duration of the neurogenic contractile response. Tone drops and duration of contractions decreases after rewarming.

The neurogenic contractile response to field stimulation was often enhanced by moderate elevations in temperature. Often this enhancement was preceded by a period of inhibition (Figs. $6 \mathrm{~A}, 7 \mathrm{~A})$. At higher temperatures $\left(41-43^{\circ} \mathrm{C}\right)$ the neurogenic response diminished. At $45^{\circ} \mathrm{C}$ the neurogenic contractile response was abolished. It was, however, not irreversibly deteriorated but reappeared after chilling (Fig. 4D). Pretreatment of the preparations with sotalol $(3-30 \mu \mathrm{mol} / \mathrm{l})$ or addition of sotalol during response to heat did not influence the tonic response of the preparations or their response to field stimulation of intramural nerves.

Chilling (to $20-34^{\circ} \mathrm{C}$ ) of preparations that had been warmed $\left(39-45^{\circ} \mathrm{C}\right.$ ) induced relaxation (Figs. 4D, 6A, 7C and D). The relaxation was usually fast when the change in temperature was rapid and slow when the change was gradual (Figs. 6A vs 7D). 
WALL LONGITUDINAL
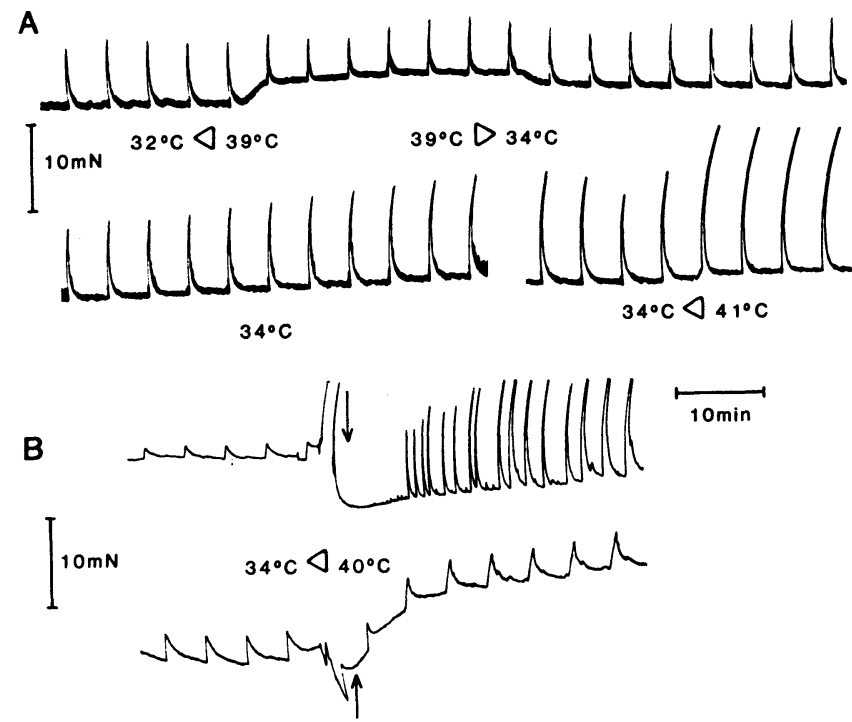

F i g u r e 6. Effect of rapid changes in temperature on tone and responses to field stimulation of intramural nerves of teat smooth muscle taken from the wall of the cistern. Field stimulation: $0.2 \mathrm{~ms}$, $10 \mathrm{~Hz} 15 \mathrm{~s}$ at $5 \mathrm{~min}$ intervals). A. Rapid warming produces contraction and decrease in response to stimulation of the nerves. After rapid chilling the tone drops again and the response to nerve stimulation increases in size. The contractions continue to increase at the low temperature, however, when now rapid warming is performed the response to nerve stimulation is increased. $B$. Two strips from the same udder show different response to rapid warming. In the upper tracing there is an immediate contraction whereafter the preparation develops spontaneous activity but does not respond to field stimulation any more. In the lower tracing the preparation relaxes but later on it gains in tone and there is some increase in the size of the response to nerve stimulation. Nerve stimulation parameters as in $A$. Arrows indicate shift in the base line.

\section{DISCUSSION}

Judging by our results we believe that the following conclusions are valid.

1. In teat smooth muscle adrenergic nerve stimulation preferentially activates $\alpha$-adrenoceptors. Part of these adrenoceptors must therefore be regarded as innervated. The response to neurogenically released noradrenaline is contraction. 
WALL LONGITUDINAL

A

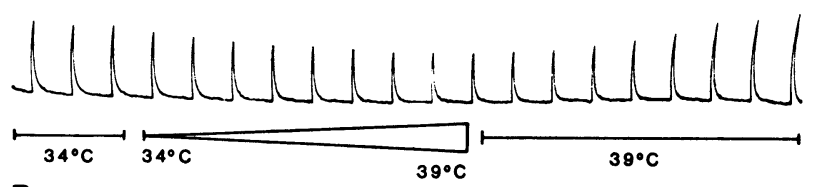

B
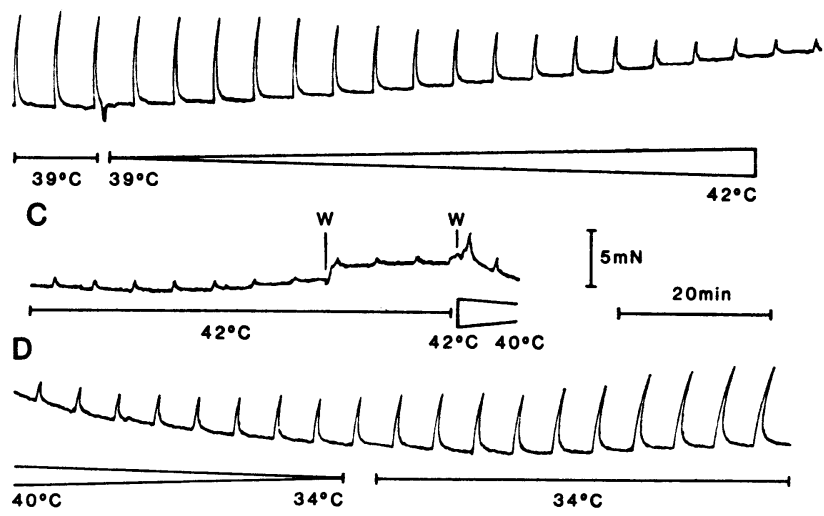

Figure 7. Effect of changing the bath temperature on the neurogenic contractile response of strips from the wall of the teat cistern. Stimulation parameters $0.2 \mathrm{~ms}, 10 \mathrm{~Hz}, 15 \mathrm{~s}$ at $5 \mathrm{~min}$ intervals. $A$. When bath temperature is gradually increased from $34^{\circ}-39^{\circ} \mathrm{C}$ the neurogenic response is attenuated. However, after a while at $39^{\circ} \mathrm{C}$ it regains its initial magnitude. $B$. A further increase in temperature to $42^{\circ} \mathrm{C}$ produces increase in tone of the muscle and attenuation of the response to nerve stimulation. In $C$ the attenuation is further illustrated. $D$. Gradual chilling of the preparation produces relaxation and the contractile response to field stimulation increases again. $\mathrm{W}=$ washing.

2. We have confirmed the presense of $\beta$-adrenoceptors in bovine teat smooth muscle. However, our results do not indicate that a substantial part of the $\beta$-adrenoceptors are closely innervated. Neurogenic $\beta$-adrenoceptor mediated relaxation could be observed after $\alpha$-adrenergic blockade and artificial increase in tone produced by barium chloride. The $\beta$-adrenergic response revealed after these procedures required long stimulation and developed after long latency. Consequently we doubt its functional significance.

3. Because $\beta$-adrenergic effects could be obtained by exogenous administration of noradrenaline and adrenaline it is plausible that in vivo activation of humoral $\beta$-adrenoceptors might have some physiological significance. 
4. The neurogenic response of the teat sphincter is less sensitive to $\alpha$-adrenergic blockade than that of other teat muscles. Furthermore, in the sphincter the neurogenic contractile response is enhanced by low concentrations of phentolamine. This enhancement is probably explained by increased secretion of the adrenergic transmitter caused by blockade of prejunctional $\alpha$-adrenoceptors (vide Alberts 1982). These features of the neurogenic response of the sphincter together with the larger noradrenaline concentration in the sphincter suggest that the neuroeffector arrangement is more intimate in the sphincter than in other parts of the teat smooth muscle. Consequently the neurogenic control may be more efficient in the sphincter region than in other regions of bovine teat smooth muscle.

5. The efferent innervation of the teat smooth muscle seems to be exclusively adrenergic, i.e. we obtained no positive evidence for either excitatory or inhibitory nerves other than adrenergic.

6. The automaticity of the teat muscle and its active response to stretch places it into the category of single unit smooth muscle. The more rapid and phasic type of activity seen in the sphincter suggests a better and more rapid conductivity and propagation in this more compact part of the teat smooth muscle than in the other parts. It is likely that this difference is of functional significance.

7. In a moderately cold environment the response to adrenergic nerve stimulation is greater than in a warmer environment. This is in accordance with results obtained on many other tissues and presumably reflects to some extent a decreased reuptake of the transmitter (e.g. Buckner et al. 1975). This is probably of physiological significance.

At very low temperatures the teat did not respond to nerve stimulation. Most likely this is explained by the wellknown phenomenon of neuronal conduction blockade at low temperatures. The decreased sensitivity to adrenergic nerve stimulation seen at higher temperatures may be of functional significance and could contribute to the flaccidity that is seen when milking or sucking has taken place for a while.

Combined with field observations our results and conclusions may contribute to the understanding of some so far poorly understood teat reactions occurring in the cow before and during milking. 
In cows with empty teat cisterns between the milkings and in most other lactating mammals shortening of the teat and stiffening of the teat wall occur when the udder is being prepared (stimulated) for milking ("stage 1"). Most likely this reaction is caused by reflex discharges in the adrenergic nerves $(\alpha$-adrenergic response). The streak canal sphincter and the smooth muscle of the gland cistern wall (own field observations) react in the same way as the muscle of the teat wall, i.e. they contract on stimulation. Contraction of the cisternal muscle may initially contribute to the increase in intramammary pressure that occurs in milking. However, within few seconds after the teat muscle contraction the teat becomes flaccid, it increases in length and width and the teat cistern becomes expanded by milk ("stage 2"). Milking or sucking can now start apparently without substantial support of myoepithelial contraction (so-called passive withdrawal). "Stage 2" is followed by "stage 3" characterized by the well-known oxytocin-mediated myoepithelial contraction and active milk ejection.

"Stage 2" corresponds to the milk let-down (German: Einschiessen) in the original popular meaning of the expression (Fürstenberg 1868 and later investigators). The flaccidity of the teat remains for the whole milking as can be observed on intentional and unintentional interruption of the milking as well as after the final detachment of the cluster. Thus, the muscle does not seem to respond by contraction to the massaging action of the pulsating liner. Decreased $\alpha$-adrenergic response due to warming may contribute in the relaxation of the muscle. It is, however, not likely that neurogenic muscle relaxation via activation of $\beta$-receptors plays a significant role in the relaxation.

In cows using their teat cisterns as milk receptacula between the milkings, a distinct "stage 1" can usually not be observed. The teat cisterns are already expanded by milk and the teat walls are warm when the specific premilking stimulation starts. This may be an effect of lack of storage space for the secreted milk in the quarter cisterns. The development of the dairy cow towards higher yield does not seem to have been paralleled by sufficient increase in the storage capacity of the quarter cisterns.

Due to its more effective neuromuscular arrangement the sphincter may initially be less sensitive than the teat wall to the decrease in tonus in "stage 2". However, when milking starts and the streak canal is forced open by the milk flow the tonus 
will be lowered. The width of the canal should then be determined, principally and within anatomically set limits by the pressure gradient across the canal. During machine milking the canal becomes closed by compression of the teat tip when the liner collapses - not by contraction of the sphincter as is sometimes assumed.

In cows with expanded teat cisterns before milking time rhythmically repeated teat contractions and milk leakage often occur, yet not simultaneously in the same cow. It is likely that the contractions are provoked by the stretch in itself. They are not synchronized when appearing in more than one teat in a cow what suggests a local origin.

When milk leakage occurs the tone of the sphincter is not large enough to withstand flow through the canal. Milk leaves the udder as drops or jets from one or more teats of the cow. Pinching the teat or sometimes even a slight touch of the teat wall elicits contraction of the sphincter. The leaking immediately ceases but often recurs after a while. The provoked interruption af the leakage is most likely due to neurogenic stimulation via $\alpha$-receptors of the teat muscle, in particular the sphincter, resulting in contractions.

Tight streak canal closure is sometimes encountered when premilking squirting or milk sampling is to be done. Extraordinary force is then required to extract even a very thin milk jet, although there may be milk enough in the teat cistern for a jet of ordinary width. Provided that there is no morphological stenosis the main cause of this phenomenon seems to be strong contraction of the sphincter mediated by adrenergic nerves and elicited in connection with discomfort in the cow. This interpretation is supported by the fact that local anaesthetics introduced into the streak canal promptly abolish the contraction (own observations).

Sudden cessation of the milk flow during milking may occur when the cow experiences some sort of discomfort. It is due to contraction of the teat muscle including the sphincter and the muscle of the gland cistern wall. Teat and gland cisterns decrease in size and the streak canal is closed. This reaction is very sudden which suggests that it is essentially mediated via the adrenergic nerves of the udder, not by circulating catecholamines from the adrenal medulla.

Warming or chilling of the teat skin, within reasonable limits, 
as part of the preparatory premilking procedures has likely no substantial effect of its own.

Presumably the essence of our findings is also valid for the teat and teat homologue (nipple and areola) of other mammals including the human female. Erection of the nipple is for developmental reasons probably very similar to raising of the hair. Most likely the teat smooth muscle shares functional properties with the arrectores pilorum. At least they have the same type of excitatory innervation.

\section{ACKNOWLEDGEMENTS}

We wish to thank Mrs. Annika Rosén for excellent assistance in making the figures and Mrs. Kerstin Westling for excellent technical assistance. Financial support from the Albert Hjärre Stiftelsen and Stiftelsen Lars Hiertas Minne is gratefully acknowledged.

\section{REFERENCES}

Alberts, $P$.: Mechanisms of facilitation and muscarinic or $\alpha$-adrenergic inhibition of acetylcholine and noradrenaline secretion from peripheral nerves. Acta physiol. scand. 1982, Suppl. 506.

Buckner, C. K., K. Bohuski \& C. F. Ryan: Influence of temperature and cocaine on responses of the isolated mouse vas deferens to adrenergic amines. Arch. int. Pharmacodyn. 1975, 216, 1927.

Chang, C. C.: A sensitive method for spectrophotofluorometric assay of catecholamines. Int. J. Neuropharmacol. 1964, 3, 643-649.

Fürstenberg, M. H. F.: Die Milchdrüsen der Kuh. (The bovine mammary glands). Wilh. Engelmann, Leipzig 1868.

Klinge, E. \& N. O. Sjöstrand: Comparative study of some isolated mammalian smooth muscle effectors of penile erection. Acta physiol. scand. $1977,100,354-367$.

Linzell, J. L.: Mammary blood flow and methods of identifying and measuring precursors of milk. In: Lactation. A comprehensive treatise. Vol. 1. Eds. B. L. Larson \& V. R. Smith. Academic Press, New York and London 1974, pp. 143-225.

Peeters, G. J.: Milk ejection and synthèsis of milk in ruminants. In: Physiology of Mammary Glands. Eds. A. Yokoyama, H. Mizuno \& H. Nagasawa. Japan Sci. Soc. Press, Tokyo \& Univ. Park Press, Baltimore 1978, pp. 22-39.

Sjöstrand, N.O.\& G. Swedin: On the mechanism of the enhancement by smooth muscle stimulants of the motor responses of the guinea-pig vas deferens to nerve stimulation. Acta physiol. scand. $1974,90,513-521$.

Sjöstrand, N.O.\& G. Swedin: Influence of age, growth, castration and testosterone treatment on the noradrenaline levels of the ductus deferens and the auxiliary male reproductive glands of the rat. Acta physiol. scand. 1976, 98, 323-338. 


\section{SAMMANFATTNING}

Neurogent och myogent betingade reaktioner i den glatta muskulaturen i preparationer från spenar hos kor.

Preparationer (strips) av den glatta muskulaturen i kospenar har studerats. Innervationen har undersökts genom analytisk farmakologi på fältstimulerade preparationer. Innehållet av noradrenalin i spenväggen och spenkanalsfinktern har bestämts. De huvudsakliga resultaten är följande. Spenens glatta muskulatur reagerar som „singleunit" muskulatur, d. v. s. den är spontanaktiv och svarar på sträckning med kontraktion. Särskilt sfinktern har förmåga till snabb fasisk rytmicitet. Spenmuskulaturen har excitatorisk adrenerg innervation. Noradrenalin från nervändarna aktiverar i första hand $\alpha$-adrenoceptorerna under det att $\beta$-adrenoceptorer främst aktiveras humoralt. Sfinktern har högre koncentration av noradrenalin än annan spenmuskulatur och också effektivare neuromuskulära överledningsmekanismer, vilket sannolikt har funktionell betydelse. Måttlig avkylning ger förstärkt svar på adrenerg nervstimulering, medan uppvärmning till högre temperaturer (mer än $40^{\circ} \mathrm{C}$ ) ger motsatt effekt. Även detta har sannolikt funktionell betydelse. Normalt utgör sålunda den glatta spenmuskulaturen hos ko med dess excitatoriska adrenerga innervation ett effektivt neuro-effector system. Särskilt gäller detta spenkanalsfinktern. Resultaten diskuteras mot bakgrund av spenmuskelreaktioner in vivo.

(Received June 4, 1984).

Reprints may be requested from: Nils O. Sjöstrand, the Department of Physiology, Karolinska Institutet, S-104 01 Stockholm, Sweden. 